\title{
Availability, Accessibility and Utilization of Information and Communication Technology in Physics Teaching in Akwa Ibom State, Nigeria, West Africa
}

\author{
Utibe-Abasi Sceptre Stephen ${ }^{1}$ \\ ${ }^{1}$ Department of Science Education, University of Uyo, Uyo, Akwa bom State, Nigeria \\ Correspondence: Utibe-Abasi Sceptre Stephen, Department of Science Education, University of Uyo, Uyo, \\ Akwa bom State, Nigeria. Tel: 234-809-138-2445. E-mail: utibeabasistephen@yahoo.com
}

Received: July 8, $2013 \quad$ Accepted: August 5, $2013 \quad$ Online Published: August 16, 2013

doi:10.5539/mas.v7n9p57 URL: http://dx.doi.org/10.5539/mas.v7n9p57

\begin{abstract}
This article reports on a study which investigated availability, accessibility and utilization of Information and Communication Technology (ICT) in secondary school physics curriculum delivery. The sample of 378 physics teachers randomly drawn from the eight educational zones in Akwa Ibom State, Nigeria was used for the study. The study revealed that most of the physics teachers in Akwa Ibom State of Nigeria are aware of ICT resources such as computer set, television set, video cassettes, audio tape player, slide projector and overhead projector. Most secondary schools in the State were not connected to the internet and hence physics teachers have no access to the internet for use in physics curriculum delivery. Further finding showed that most physics teachers are not computer literate. It was further revealed that very few of the respondents used for the study were aware of the selected computer software packages used for the study and no teacher used any of the programmes to complement on their physics instructional delivery. The recommendation arising from the findings was that Government and all stakeholders in education should equip schools with sufficient quantity of modern ICT resources. Another recommendation was that physics teachers should be trained on the use of ICT in physics teaching.
\end{abstract}

Keywords: information and communication technology (ICT), physics teachers, physics teaching, Nigeria

\section{Introduction}

Application of computer and internet technology in education is a primary concern for educators all over the world (Williams, 2010). Experts, Wodi and Dokubo (2008), in the field of education are of the opinion that when properly used, ICT holds great promise to improve teaching and learning in addition to shaping work force opportunities. According to Wodi and Dokubo (2008), ICT based learning intervention can either be used to enhance practical investigation or as a virtual alternative to real practical work where a simulation supports exploration of the investigation model through a computerized representation of the phenomena under study.

In a rapid changing world of global market competition, automation, and increasing democratization, basic education is necessary for an individual to have capacity and capability to access and apply information. Such ability and capability must find bearing in Information and Communication Technology in the global village. The ability to access and effectively utilize information is no longer a luxury but a necessity for development. The use of new technological devices such as computers, internet, CD-Roms, interactive videodisc instruction, Computer Assisted Instruction, Computer Based Instruction, Computer Based Learning, e-learning, and others for curriculum delivery have been found to be very effective in physics curriculum delivery and also useful to learners in solution of learning tasks in education (Felder \& Bent, 2004). These new technologies make learning easier, faster, exciting and interesting to learners. Computer is a technology with many functions, some of which are to assist in classroom instructions, provide concrete and realistic experiences, and make information processing easier, faster, efficient and fun, scientific enquiry and scientific literacy (Nwosu, 2009). Computers, therefore can be used to enrich the existing science curriculum in general and physics curriculum in particular through the adoption of various instructional programmes.

In Nigeria research has shown that teachers and textbooks, chalkboards and traditional laboratory/workshop facilities are no longer adequate to cope with the amount and type of information skills and competences 
expected of students of science in general and physics in particular (Okwo, 2006). Okwo (2006) had previously observed that ICT or Computer Assisted Instruction (CAI) has a proven capacity to provide concrete and realistic experiences and that it makes information processing easier, faster and more efficient. This is because it brings outside experiences to the classroom thereby providing the learners the opportunity to go beyond the capabilities of their teachers. The versatility and ease with which ICT applies itself as a teaching aid or resource helps make it an indispensable tool for improved and efficient resource in physics instruction. As a result, different governments worldwide have made huge investments in computers, internet access, development and technological support (Eroha \& Ekweme, 2007).

Despite these laudable advantages, Nigeria is unfortunately behind other developed nations in ICT use as it relates to educational delivery. In a study, Cirfat, Zumyil and Ezemma (2006) discovered a dismal performance of secondary school students on factors such as manpower, knowledge and use in computer aided instruction. Researches have also shown that there is a low level of ICT awareness in most secondary institutions in Nigeria (Busari, 2006; Eroha \& Ekweme, 2007).

It is in realization of the great potentials of computers and internet in promoting effective physics curriculum delivery and also the urgent need to inculcate computer literacy in learners that prompted the Federal and State Governments in Nigeria to equip secondary schools with computers and some ICT resources for effective teaching and learning of physics in particular and other science subjects in general.

In Akwa Ibom State of Nigeria, almost all the secondary schools have some quantity of computers provided by the Federal Government, State Government, non-governmental organizations, or some philanthropists. These laudable efforts at promoting computer literacy in secondary schools and in enhancing effective physics instructional delivery by teachers through the use of computers, internet and other ICT resources do not seem to be yielding the desired results judging by students' poor performance in physics in both internal and external examinations. Several research reports (Busari, 2006; Eroha \& Ekweme, 2007) converge to indicate a lack in some cases or insufficient human and material resources in others in the area of ICT. This study was therefore undertaken to find out the availability, accessibility and level of utilization of ICT as a resource in the teaching and learning of physics in secondary schools in Akwa Ibom State of Nigeria in particular.

\section{Statement of the Problem}

It is a known fact today that the future of our educational development depends on modern technology. This technology stems from the availability, accessibility and utilization of resources such as ICT. Most schools in Akwa Ibom State of Nigeria lack both human and material resources in the area of ICT. This condition can lead to ineffective teaching and learning of science in general and physics in particular. This study was therefore undertaken to find out the availability, accessibility and extent of utilization of ICT as a resource in the teaching and learning of physics in secondary schools in Akwa Ibom State, Nigeria.

\section{Research Questions}

The following research questions guided the study.

1) Are the physics teachers in secondary schools in Akwa Ibom State aware of ICT resources for physics instruction?

2) What is the computer literacy level of secondary school physics teachers in Akwa Ibom State?

3) To what extent are computers, internet and other modern ICT resources available and accessible to physics teachers for use in physics curriculum delivery in Akwa Ibom State secondary schools?

4) What computer software packages do physics teachers use in classroom instruction in Akwa Ibom State secondary schools?

\section{Methodology}

\subsection{Research Design and Area of Study}

The design for the study was descriptive method of survey. Akwa Ibom State of Nigeria was the study area. Akwa Ibom State shares boundaries with Cross River State in the North, Abia State in West, Rivers State in the South and Cameroon in the East. Akwa Ibom State is one of the 36 States in Nigeria. The state has a department called Ministry of Education that takes charge of education matters. This Ministry of Education is sub-divided into eight educational zones for easy management and supervision of secondary schools. 


\subsection{Population of the Study}

The population of the study was all physics teachers in the eight educational zones in Akwa Ibom State. The population size was 680 physics teachers.

\subsection{Sample of the Study}

Random sampling technique was used to draw 378 physics teachers from the eight educational zones in the state. The 378 subjects responded to a 31- item questionnaire on the availability, accessibility, awareness and utilization of ICT as a resource in physics teaching. Four research questions were raised to guide the investigation. Percentages were used to analyze the data.

\subsection{Instrumentation}

A structured questionnaire was constructed and used by the researcher for collection of data. The questionnaire was made up of five sections. Section A sought information on teaching qualification, gender, age and subject taught. Section B consisted of 11 items which sought information on the physics teachers awareness of some ICT resources used in teaching science in general and physics in particular. Section C consisted of 3 items which sought information on ICT literacy of physics teachers. Section D consisted of 13 items which sought information on availability and accessibility of some modern ICT resources for physics teaching. Section E with 4 items sought information on the awareness and utilization of some selected computer software packages in physics teaching and learning.

\section{Data Collection and Analysis}

The 378 physics teachers responded to all the items in the questionnaire. The data were analyzed using simple percentages. The results for answering research questions 1,2, 3 and 4 raised are summarized in Tables 1, 2, 3 and 4 respectively.

Table 1. Responses of physics teachers on the awareness of some ICT resources

\begin{tabular}{ccc}
\hline ICT Resources & $\begin{array}{c}\text { \% that indicated awareness of some } \\
\text { ICT resources }\end{array}$ & $\begin{array}{c}\text { \% that indicated non-awareness of } \\
\text { some ICT resources }\end{array}$ \\
\hline Computer set & 80 & 20 \\
World wide & 22 & 78 \\
web(WWW) & 42 & 58 \\
Internet & 14 & 86 \\
Computer software & 16 & 84 \\
programmes & 90 & 10 \\
Transparencies & 84 & 16 \\
Video Cassette & 61 & 39 \\
Audio tape player & 55 & 45 \\
Video projector & 62 & 38 \\
Slide projector & 100 & 0 \\
Overhead projector & & \\
Television set & &
\end{tabular}


Table 2. Responses of physics teachers on computer literacy level

\begin{tabular}{lll}
\hline ICT Resources & \% literacy & \% illiteracy \\
\hline Computer & 28.0 & 72.0 \\
Mode of training in ICT literacy & & \\
(a) Seminar/workshop in school & 2.5 & 97.5 \\
(b) Seminar/workshop outside school & 3.7 & 96.3 \\
(c) Personal effort & & \\
& 75.0 & 25.0 \\
Grade of certificate acquired in computer & & \\
literacy & & \\
(a) Degree & 2.0 & 98.2 \\
(b) Diploma & 21.0 & 79.0 \\
(c) Certificate course & 48.2 & 51.8 \\
\hline
\end{tabular}

Table 3. Responses of physics teacher on the availability and accessibility of modern ICT resources in their schools

\begin{tabular}{lllll}
\hline ICT Resources & $\begin{array}{l}\text { \% that indicated } \\
\text { availability of } \\
\text { ICT Resources }\end{array}$ & $\begin{array}{l}\text { \% that indicated } \\
\text { non-availability of } \\
\text { ICT Resources }\end{array}$ & $\begin{array}{l}\text { \% that indicated } \\
\text { accessibility of ICT } \\
\text { Resources }\end{array}$ & $\begin{array}{l}\text { \% that indicated } \\
\text { inaccessibility of } \\
\text { ICT Resources }\end{array}$ \\
\hline Computer & 90.8 & 9.2 & 3.2 & 96.0 \\
Internet & 3.6 & 96.4 & 1.2 & 98.8 \\
Television set & 50.4 & 49.6 & 5.8 & 94.2 \\
Micro projector & 1.5 & 98.5 & 0.6 & 99.4 \\
Computer Discs & 15.8 & 74.2 & 6.8 & 93.2 \\
Computer software & 2.8 & 97.2 & 1.1 & 98.9 \\
programmes & & & & \\
CD-Rom & & 97.6 & 1.2 & 98.8 \\
E-mail facilities & 2.4 & 97.3 & 2.1 & 97.9 \\
World Wide Web & 2.7 & 92.5 & 3.7 & 96.3 \\
Video machines & 7.5 & 99.5 & 0.1 & 99.9 \\
Overhead projector & 0.5 & 74.7 & 6.2 & 93.8 \\
Video cassettes & 15.3 & 70.8 & 7.8 & 92.2 \\
Video Tape player & 29.2 & 94.4 & 2.2 & 97.8 \\
Transparencies & 5.6 & & & \\
\hline
\end{tabular}

Table 4. Awareness, availability and utilization of selected computer software packages by physics teachers

\begin{tabular}{llccc}
\hline S/N & Computer software packages & $\begin{array}{c}\text { Awareness } \\
\mathbf{( \% )}\end{array}$ & $\begin{array}{c}\text { Availability } \\
\mathbf{( \% )}\end{array}$ & $\begin{array}{c}\text { Utilization } \\
\mathbf{( \% )}\end{array}$ \\
\hline 1 & Star view & 5 & 0 & 0 \\
2 & SPSS programme & 20 & 4 & 0 \\
3 & Sky hunter, bird specie preservation Archimedes & 4 & 0 & 0 \\
4 & View point software simulation Archimedes & 0 & 0 & 0 \\
\hline
\end{tabular}




\section{Results and Discussion}

\subsection{Research Question 1}

The results in Table 1 revealed that most of the Physics teachers are aware of ICT resources such as computer set $(80 \%)$, television set $(100 \%)$, video cassettes $(90 \%)$, audio tape player $(84 \%)$, video projector $(61 \%)$, slide projector (55\%) and overhead projector (62\%). The results in Table 1 further revealed that most of the physics teachers are not aware of ICT resources such as World Wide Web (78\%), internet (58\%), computer software programmes $(86 \%)$ and transparencies $(84 \%)$.

\subsection{Research Question 2}

Table 2 presents the respondents computer literacy level of $28 \%$ while a high proportion of physics teacher (over $70 \%$ ) had little or no computer literacy.

\subsection{Research Question 3}

The findings of the study from Table 3 present a low percentage of 3.2\% regarding accessibility and a high percentage of $90.8 \%$ availability of computer to physics teachers. This is because many physics teachers in the secondary schools used are not computer literate. In some cases, the school principals locked them to avoid damage because of the irresponsible attitude of some of the physics teachers. Another finding was that $1.2 \%$ of the schools used were connected to the internet. The result from Table 3 further showed between $0.6 \%$ and $6.8 \%$ accessibility of other modern ICT resources such as television set, micro projector, computer discs and computer software programmes CD-Rom to physics teachers.

\subsection{Research Question 4}

The results in Table 4 showed that 5\%,20\%, and $4 \%$ of the physics teachers used for the study were respectively aware of the star view, spss programmes and Sky hunter, bird specie preservation Archimedes of the selected computer software packages for the study. The results further revealed that $4 \%$ of the 378 respondents used have spss programmes in their schools and no teacher used any of the 4 selected computer software packages in the physics teaching.

\section{Discussion of Findings}

The study investigated availability, accessibility and utilization of Information and Communication Technology (ICT) in Physics curriculum delivery. The findings of this study revealed that most Physics teachers are aware of ICT resources such as computer set, television set, video cassettes, audio tape player, video projector, slid projector and overhead projector. The results from Table 1 further showed that most secondary schools were not connected to the internet; hence physics teachers had no access to the internet for use in physics curriculum delivery. These findings are in agreement with the findings of Nwosu (2009) who found that secondary schools in Nsukka urban Area of Enugu State, Nigeria have few computers which are used for administrative purposes but not for educational purposes or as teaching aids in physics instruction. This implies that the number of computers available in schools is not enough for the students' population.

The findings in Table 2 showed only $28 \%$ of the physics teachers used are computer literate. This lack of technical knowledge to computers and consequently lack of appropriate skills in the use of modern ICT resources by physics teachers has resulted in both teachers and students being denied access to a powerful and effective teaching and learning tool in a country where level of students' academic performance in physics is low (Chief Examiners WAEC report 2007, 2008, 2009). The few physics teachers that have acquired ICT training were discovered to have acquired the training through seminars/workshops outside school.

The findings in Table 3 showed that computers are available in most of the secondary schools used. About $90 \%$ of the schools have computers, out of which 3.2\% were accessible for use in Physics curriculum delivery. About $3.6 \%$ of the schools have internet services while a very low percentage of $1.2 \%$ was accessible for physics instruction. The results in Table 3 further showed between $2.8 \%$ and $50.4 \%$ availability; and between $0.6 \%$ and $6.8 \%$ accessibility of other modern ICT resources used for the study. These findings deprive students and Physics teachers of the benefits derivable from the use of these ICT resources in Physics instruction. These findings support the findings of Okwo (2006) who found that secondary schools in Anambra State of Nigeria are lacking behind in terms of acquisition and usage of modern ICT resources in Science Curriculum delivery.

In Table 4, the finding showed that a very low response of $29 \%$ of 378 respondents used for the study were aware of the 4 computer software programmes provided. About $4 \%$ of the 4 computer software packages used for the study was available for use by the physics teachers to compliment on their Physics Instructional delivery 
in this age of computer aided instruction (CAI). The result further showed that none of the selected computer software packages was used in physics curriculum delivery by physics teachers.

\section{Conclusion/Recommendation}

The conclusions made from the findings of the study were that physics teachers are ignorant of educational software programmes that are available, physics teachers are not keeping pace with recent ICT technologies available for physics instruction and most of the physics teachers are not computer literate and hence are ignorant of ICT resource materials.

The recommendations from findings are:

1) School authorities and government of the state should provide internet for all schools.

2) Resource materials such as computer software programmes should be provided to schools to assist physics teachers to play their role effectively.

3) There should be provision of the available new ICT resources that could be used for physics teaching and training of physics teachers on the use of ICT resources in physics instructional delivery.

\section{Acknowledgements}

I write to acknowledge the contribution of Mfon Effiong Udo in proof reading this article. Mfon Effiong Udo is of the Department of Science Education, University of Uyo, Uyo, Akwa Ibom State, Nigeria. He introduced me to Journal of the Canadian Centre of Science Education.

Acknowledgement also goes to Bliss Stephen for his writing assistance. Bliss Stephen is a lecturer in the Department of Electrical/Electronic and Computer Engineering, University of Uyo, Uyo, Akwa Ibom State, Nigeria.

\section{References}

Busari, I. (2006). An investigation into training status and ICT support of Teacher's Trainers in higher learning in Lagos state. In M. A. G (Ed.), STAN $44^{\text {th }}$ Annual Conference Proceedings on Information and Communication Technology (pp. 53-58). Ibadan: Heinemann Educational Books.

Chief Examiners Report (2007, 2008, 2009). West African Examination Council Nigeria.

Cirfat, A., Zumyil, C., \& Ezemma, M. (2006). The states of ICT in Colleges. In M. A. G. (Ed.), STAN $44^{\text {th }}$ Annual Conference Proceeding on Information and communication Technology (pp. 48-52). Ibadan: Heineman Educational Books.

Eroha, K., \& Ekweme, C. (2007). Assessment of Teachers level of literacy and Attitude towards information and Communication Technology (ICT) Application in STM Education. In M. A. G Akale (Ed.) STAN $44^{\text {th }}$ Annual Conference Proceedings on Information and Communications Technology (pp. 14-17). Ibadan: Heinmann Educational Books.

Felder, R., \& Bent, R. (2004). Navigating the bumpy road to student-centered Instruction. Communication Technology (pp. 48-52). Ibadan: Heinemann Educational Books.

Nwosu, A. (2009). Effects of Computer-Assisted Instruction (CAI) with drill and practice on academic achievement of students in physics. Nig. J. Science and Science Edu., 8(2),72-86.

Okwo, F. (2006). Communicating STM with New Media: Status and implications. In A. O. Olarewaju (Ed.), STAN $39^{\text {th }}$ Annual Conference Proceedings on Communication STM (pp. 80-82). The Shell Petroleum Company of Nigeria Ltd. World Bank (2002) Information and Communication Technologies: A World Bank Strategy Washington United States Education Report.

Williams, K. (2010). Using information technology: A practical introduction to computer and communication. $J$. Science Teach. Nig., 4(1), 174-180.

Wodi, S., \& Dokubo, A. (2008). The relevance of ICT in Science and technology. J. Curr. Organ., 13(1), 160-166.

\section{Copyrights}

Copyright for this article is retained by the author(s), with first publication rights granted to the journal.

This is an open-access article distributed under the terms and conditions of the Creative Commons Attribution license (http://creativecommons.org/licenses/by/3.0/). 